\title{
Self-organization of foraging behaviour: From simplicity to complexity without goals
}

\author{
Frederick D. Provenza', Juan J. Villalba', Carl D. Cheney ${ }^{2}$ and Scott J. Werner ${ }^{1}$ \\ 'Department of Rangeland Resources, Utah State Univ., Logan, Utah, U.S.A. 84322-5230 \\ ${ }^{2}$ Department of Psychology, Utah State Univ., Logan, Utah, U.S.A. 84322-2810
}

\begin{abstract}
A herbivore faces challenges while foraging-ongoing changes in its physiological condition along with variation in the nutrient and toxin concentrations of foods, spatially and temporally-that make selecting a nutritious diet a vital affair. Foraging behaviours arise from simple rules that operate across levels of resolution from cells and organs to individuals and their interactions with social and physical environments. At all these levels, behaviour is a function of its consequences: a behaviour operating on the environment to induce changes is itself changed by those events. Thus, behaviour emerges from its own functioning-behaviour selforganizes-not from that of its surroundings. This ostensible autonomy notwithstanding, no self-organizing system (cell, organ, or individual) is independent of its environs because existence consists of an ongoing exchange of energy and matter. According to this view, the notion of cause and effect is replaced with functional relationships between behaviours and environmental consequences. Changes in physical environments alter the distribution, abundance, nutritional, and toxicological characteristics of plants, which affect food preference. Social interactions early in life influence behaviour in various ways: animals prefer familiar foods and environments, and they prefer to be with companions. Animals in unfamiliar environments often walk farther, ingest less food, and suffer more from malnutrition and toxicity than animals in familiar environments. An individual's food preferences--and its ability to discriminate familiar from novel foods--arise from the functional integration of sensory (smell, taste, texture) and postingestive (effects of nutrients and toxins on chemo-, osmo-, and mechano-receptors) effects. The ability to discriminate among foods is critical for survival: all problems with poisonous plants are due to an inability to discriminate or a lack of alternatives. Animals eat a variety of foods as a result of nearing or exceeding tolerance limits for sensory and postingestive effects unique to each food. After eating any food too frequently or excessively, the likelihood increases that animals will eat alternative foods owing to exceeding sensory-, nutrient-, and toxin-specific tolerance limits. Cyclic patterns of intake of a variety of foods reflect seemingly chaotic interactions among flavours, nutrients, and toxins interacting along continua.
\end{abstract}

\section{Introduction}

"Eventually, all things merge into one, and a river runs through it. The river was cut by the world's great flood and runs over rocks from the basement of time. On some of the rocks are timeless raindrops. Under the rocks are the words, and some of the words are theirs. I am haunted by waters." (Maclean, 1976) 
Some suggest that conventional models of foraging lack high level goals, which they contend are needed to explain how animals assess the value of foods (Day et al. 1998). Their objective is to clarify how animals identify new foods and how individuals monitor changes in the nutritional qualities of foods. They maintain that information gathering (exploratory behaviour) occurs at two levels: (1) intrinsic motivation is used to discriminate food from nonfood items, and (2) extrinsic motivation is used to monitor nutrient and toxin concentrations in familiar foods. As Toates (1997) suggests "either an exceedingly fortuitous sequence of stimulus-response connections lead an animal to a 'functional end-point' that is not even present at the time the sequence starts, or a high level goal must be postulated".

In contrast, we believe animals assess changes in nutrient and toxin concentrations in foods without intrinsic or extrinsic motivation or high level goals. We argue that complex behaviours such as foraging arise from simple rules that operate at all levels of resolution from cells and organs to individuals and their interactions with social and physical environments. Appeals to hypothetical agencies such as motivation and high level goals serve no function in behaviour analysis, which is distinct from mainstream experimental psychology in that its historical influences have led to the development of a descriptive, functional, and integrative system of principles (Skinner, 1981; Cheney, 1994; Chiesa, 1994). Thus, there can be little generalization of precepts across the two approaches.

\section{Behaviour by consequences}

The law of parsimony-Occam's Razor-holds that the preferred theory is the one with the fewest assumptions. This law is violated unnecessarily by those who infer inner reasons (high level goals, intrinsic and extrinsic motivation) upon observing an animal behaving. To assert that the cause of an animal's movement comes from an "inner need to explore" or a "drive to gain information" does not help to explain behaviour. Frequently, such "explanations" do nothing more than restate the observation.

For example, a bird observed poking pine nuts under a stick returns later and eats the nuts. Claiming that the bird retrieved the nuts because it remembered means only that the bird put the nuts there and then came back and got them. The label "remembering" merely describes the bird's actions; it is not a functional account of its behaviour. Similarly, a pig does not lift a feeder door because it expects or is motivated to find food. Rather, the pig lifts the door because it has performed the behaviour and obtained food in the past. Referring to expectation or saying the behaviour is goal-directed or shows purpose adds nothing to the explanation. As Ryle (1949) points out, the lift is the expectation.

It is also a circular explanation to say a pig eats grain to stay healthy. The pig is said to have a purpose because of its behaviour and then is said to exhibit the behaviour because of the purpose. An individual does not have eyes in order to see; rather, its ancestors transmitted the advantage. Behaviours are not present to gain future advantage, they are present because of past consequences. Behaviours so conditioned are not always adaptive: animals eat foods that are not healthful, and they engage in sexual behaviours that do not lead to procreation (Skinner, 1981). Nor is every individual in a population equally fit. For populations, nature counters environmental variation with fecundity, and morphological and physiological variation. For individuals, nature counters environmental variability with adaptability; individuals cope with an ever changing environment by constantly adapting (Provenza et al. 1998).

We do not object to labels per se-we use them throughout this paper (e.g. self-organization, reinforcement, learning, neophobia, palatability)_-but to labels improperly used as 
explanations for hypothetical and contrived entities such as motivations and expectations, which have never been located in animals (Brothers, 1997). The shortcomings of contrived inner mechanisms notwithstanding, neurological, morphological, and physiological processes are functional and observable phenomena that underlie behaviour (see sections on self-organization, individual experience, and varied diets).

What influences the behaviour of a cell, organ, individual, or social group? Extensive data have shown that the variables influencing behaviour of individuals reside throughout the environment, from cells and organs to social and physical environments, and that behaviour is a function of its consequences (Figs 1,2). If the probability of occurrence of a behaviour increases owing to contingent delivery of some item or event, then that item or event, by definition, is a positive reinforcer and the procedure is called reinforcement. If the probability of a response decreases after the contingent delivery of some item or event, that consequence is considered aversive and the procedure is called punishment. Positive reinforcement increases response frequency and punishment decreases response frequency. Behaviour of individuals is influenced by morphology and physiology: nerves, glands, organs, muscles, and skeletons. Animals behave because they are alive-nerves fire, organs, glands, muscles, and bones respond-animals are alive because they behave. Nothing could be simpler (Fig. 1) or account for so much behaviour at so many levels (Fig. 2) with so few assumptions.

The term operant (as in operant behaviour, Skinner, 1938) was coined in part to indicate that cells, organs, individuals, social groups, and physical environments operating on their environment are themselves changed in the process (Figs 1,2). Ongoing interactions between the individual and the environment transform both the individual and the environment. The body influences the structure of experience, which in turn influences the structure of the body. Environments shape individuals, which in turn shape environments. In the case of foraging, herbivores preferentially ingest foods high in nutrients and low in toxins, and in the process they constantly change the abundance and nutritional quality of foods and thus subsequent ingestion (Bryant et al. 1991; Hobbs, 1996).

\author{
Behaviour by \\ consequences
}
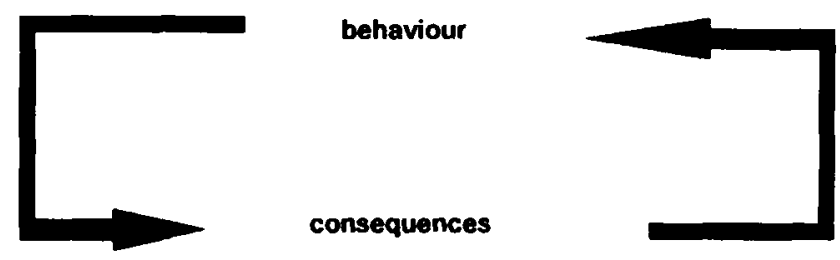

Figure 1. Behaviour by consequences is based on the premise that the consequences of behaviours affect the kinds and likelihoods of future behaviours. A behaviour that operates on the environment to induce changes is itself changed by those events. As environmental contingencies and consequences change, so does behaviour. If the probability of the occurrence of a behaviour increases due to the contingent delivery of some item or event, then that item or event, by definition, is a positive reinforcer and the procedure is called reinforcement. On the other hand, if the probability of a response decreases after the contingent delivery of some item or event, then that consequence is considered aversive and the procedure is called punishment. Positive reinforcement increases response frequency and punishment decreases response frequency. 


\section{Ever changing nature of relationships}

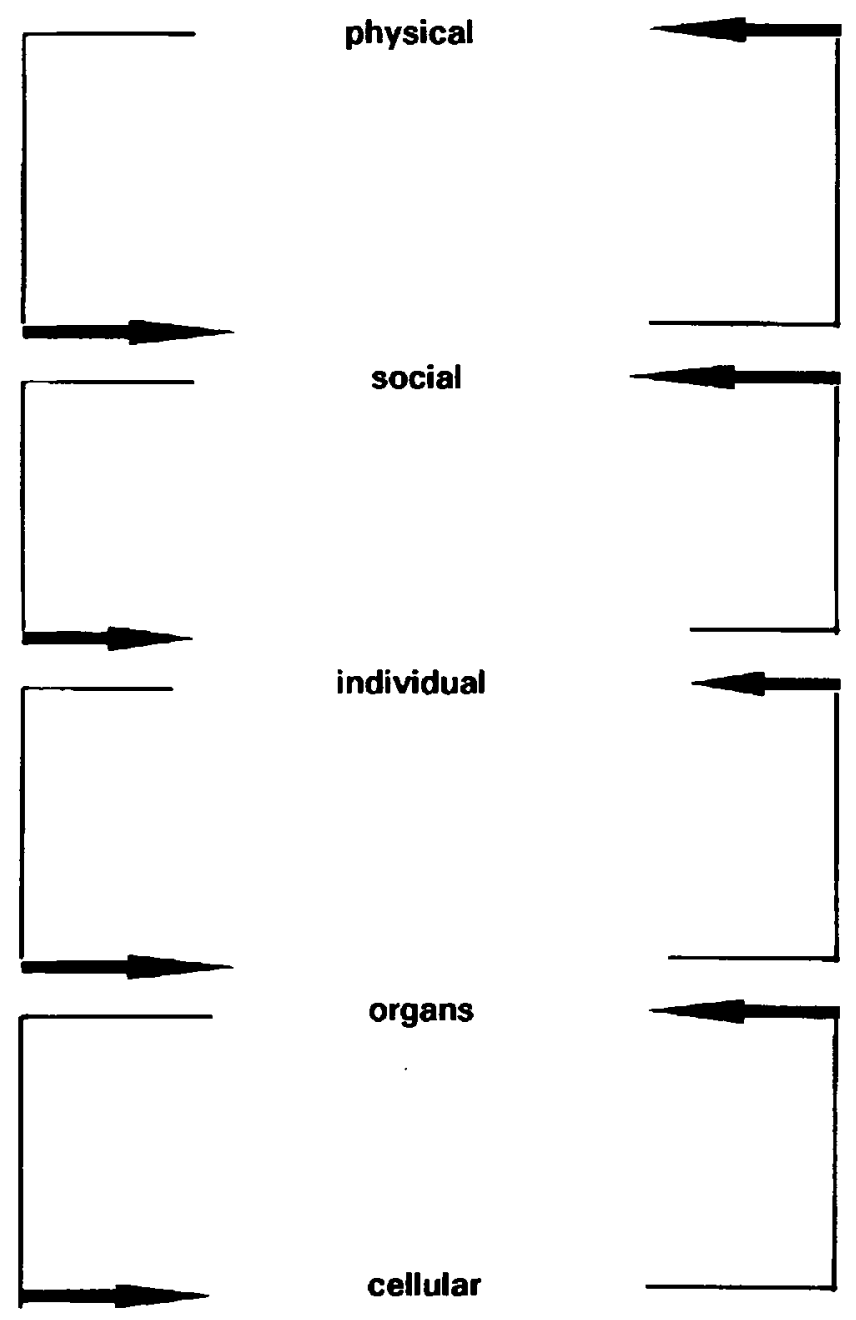

Figure 2. Life is a multidimensional web of interconnected strands. Thus, changes at any level of organization in the environment lead to changes in behaviour at all other levels. For instance, for responses (behaviour) of a cell, independent (or manipulated) environmental variables emerge from cellular, organ, individual, social, and physical processes, and the cell is the arbiter of consequences; for individual responses, the independent variables emerge from cellular, organ, social, and physical processes, and the individual is the arbiter of consequences; for responses of a social group, independent variables emerge from cellular, organ, individual, and physical processes, and the social group arbitrates consequences. The ever changing nature of relationships, involving the continual exchange of energy and matter, enables perpetually novel forms and behaviours to emerge at all levels of organization. 
In this system of behaviour analysis, as opposed to push-pull causality, a cause is replaced with a change in the independent variable (the environmental or manipulated variable) and an effect is replaced with a change in the dependent variable (the animal's response). Thus, the notion of cause and effect is replaced with functional relationships between behaviours and environmental consequences (Figs 1,2), "explanation is reduced to description and the notion of function [is] substituted for that of causation" (Mach, 1960); goals and purpose yield to being, and as the world changes, being gives way to becoming. In that sense, behaviour selforganizes (Maturana \& Varela, 1980; Prigogine \& Stengers, 1984; Provenza \& Cincotta, 1993), and there is no need to posit models, labels, or goals. Behaviour at all levels exists as its ongoing functioning (Fig.2).

\section{Self-organization of behaviour}

\section{Characteristics of self-organization}

Self-organizing systems create order out of chaos without a need to invoke external intervention or goals (Prigogine \& Stengers, 1984; Kauffman, 1995). As Kelso (1995) points out, "Selforganizing systems have no... ghost in the machine ordering the parts. Hence ... the questions of who sets the reference value, who programs the computer, who programs the programmer, and so on do not even arise". There are no inputs or outputs in a self-organizing system-no distinctions between antecedents and consequences-merely circular arrangements of functionally connected components. Hierarchies of organization and high level goals reflect the observer's logic, not the system's ongoing functioning, and constructions regarding causation are "merely metaphors of control ... that reflect the theorist's framework of assumptions as well as the limitations imposed by observational methods" (Kaplan \& Kaplan, 1991). Self-organizing systems exist as their ongoing functioning, self-regulated by dynamic feedback loops.

The order and behaviour of systems emerge from their own functioning, not from that of their surroundings, and the system's functional integrity is the variable that is maintained (Maturana \& Varela, 1980): examples include chemical clocks, lasers, and clouds in the physical realm; cells, individuals, and social groups in the biological domain; solar systems, galaxies, and universes in the cosmological sphere. This ostensible autonomy notwithstanding, no self-organizing system is independent of its surroundings. The system continually exchanges energy and matter with its environment: existence is intake and excretion, and within this interactive dialogue between organism and surroundings, life lives on life.

Seemingly distinct components of self-organizing systems, each described by the term 'holon' (Hollick, 1993), interact to create global behaviour without comprehensive or global knowledge (Stickland et al. 1995). A holon is an autonomous entity when viewed from its constituent subsystems (an individual from the perspective of an organ or cell) but from another perspective it is merely a component of a larger system: an individual as a member of a social group or as a component of a physical landscape. A holon's behaviour influences behaviour on larger scales, which in turn influences behaviour on smaller scales (e.g. gametes create cells which create individuals which create social groups which create individuals which create gametes), but no holon needs global knowledge to function (Fig. 2).

Holons are self-controlled by and interact with other holons through feedback loops. Feedback loops are a circular arrangement of functionally connected links (recursive application of simple rules) that interact until the last link in the loop feeds back to the first link in the cycle, resulting in the self-regulation of the system. Feedback influences behaviour through 
actual, rather than expected, performance (Capra, 1996). Through feedback loops, the present state of the system influences its behaviour at the next time interval, and thus the functioning of the system is never independent of its history (Capra, 1996). Nonlinearities in any of the loops create nonlinear systems (e.g. an individual's behaviour is influenced by environmental consequences and affected by subsequent form and functioning of the individual). Feedback loops are sensitive to fluctuations and perturbations which, when amplified through a system, create change. In an individual, historic and external influences involve physical, social, organ, and cellular processes; for social behaviour, history and external influences involve physical, individual, organ, and cellular processes (Fig. 2) (May, 1986; Glass et al. 1988; Glass \& Mackey, 1988; Glass \& Malta, 1990; Cole, 1994). Behaviour at all these levels is a function of consequences (Figs 1, 2).

In self-organizing systems, feedback involves more than the linear causality presumed to underlie the control of physical (e.g., temperature control by a thermostat) and physiological (e.g. intake regulation) variables. Within the links of a feedback cycle, and among interrelated feedback cycles, there are numerous possible responses with no feedback regulated set points or reference values (Kelso, 1995). The possibilities are limited only by system boundaries (e.g. the range of behaviour of a neuron is constrained by its connections to other neurons). Time delays (Glass et al. 1988) and fluctuations (Kelso, 1995) associated with the detection of a disturbance and the ensuing responses give rise to different response patterns. Thus, feedback cycles do more than simply maintain variables within normal limits. They increase the flexibility and adaptability of responses.

Self-organizing systems are perpetually in the process of becoming, but what they will become cannot be predicted with certainty. The path followed during existence depends on history, necessity, and chance (Prigogine \& Stengers, 1984). Thus, when we look back over the life of a self-organizing system it may seem to have had a consistent order and plan, but events that seemed accidental and of little moment at the time when they occurred turn out to be indispensable ingredients in the composition of a consistent plot. When we look to the future, we realize that the rest of the tale cannot be foretold because as yet unknown fluctuations and perturbations make the system's journey impossible to predict.

\section{Life is self-organization}

Chemicals self-organize into life (Kauffman, 1995), and the foraging behaviour of social insects illustrates how simple rules lead to complex patterns of social organization and movement (Goss et al. 1990; Millonas, 1992; Stickland et al. 1995; Bonabeau et al. 1997). For example, ants are influenced by a trail pheromone that guides fellow workers from the nest to food sources. When more than one trail is present, the interaction between foragers and pheromone trails enables selection of the shortest path to food or to the best food source. In marking a trail, each ant modifies the ensuing ant's probability of choosing a path, a feedback loop that rapidly, and nonlinearly, leads to one of two forks or bifurcations in a path becoming preferred. The strength of the pheromone trail is related not only to trail length, but also to the amount and nutritional quality of food at different locations. As food abundance and quality increase in certain areas, more ants forage in those locations; conversely, as food supplies diminish, the strength of the pheromone signal declines, and ants move to new locations. Thus, ants' exposure to the pheromone trail affects foraging, which in turn affects the availability of forage, and subsequent foraging (Figs 1, 2). Movement along pheromone trails, amplified through the ant colony and environment, leads to complex, dynamic, and highly organized 
behaviours. As Goss et al. (1990) point out "the interactions between the foragers and the food sources can lead to some remarkable foraging patterns, giving the illusion that the foraging force is obeying a complicated global blueprint".

Cells within ants are self-organizing systems too. Cells are living networks in which organelles produce and transform other organelles such that the cell continually remakes itself (Maturana \& Varela, 1980). The behaviours of numerous organelles and processes (and nearly 100000 different kinds of molecules) are coordinated as energy and matter are exchanged across a cell's boundaries (Kauffman, 1995). For instance, DNA in the cell nucleus produces RNA, which contains instructions for the synthesis of proteins, which contribute to cell synthesis (Capra, 1996). A special group of these proteins can recognize, remove, and replace damaged sections of DNA. The components of this partial network help produce and transform other components, such that the cell's order and behaviour are not imposed from without, but are dictated by the system itself. This apparent autonomy notwithstanding, a cell must constantly exchange energy and matter with its surroundings. Even mitochondria, the autonomous powerhouses of the cell, must interact with their surroundings to obtain energy and nutrients.

Interactions between ants and the environment are integrated neurally. Each individual's behaviour is based on local information (pheromone trail) processed through a flux of signalsneurons, action potentials, neurotransmitters (Millonas, 1992). On average, any neuron forms thousands of synapses with other neurons. At some synapses, dendrites of the neuron receive incoming information from other neurons; at other synapses, axons from the neuron provide information to other neurons. In higher animals there are billions of neurons with trillions of synapses, and as a result the response of any one neuron may appear trivial, and the complexity of the central nervous system (CNS) may seem overwhelming, but not when the CNS is viewed as a self-organizing system in which simple rules (a neuron can either fire or not) operating from neurons, local circuits, subcortical nuclei, and cortical regions, to systems and systems of systems lead to complex organization (Damasio, 1994).

During gestation, only a small percentage (about $1 \%$ in humans) of synaptic circuits are formed. As an animal develops and matures, its brain does not stop to make millions of new circuits and then begin again to use them. Rather, the brain is reassembled throughout life, and ongoing interactions with the environment reconfigure the brain as it integrates experiences with their effects on the body (Aoki \& Siekevitz, 1988; Kalil, 1989; Shatz, 1992; Damasio, 1994). The profound influence of neural integration during development is easily overlooked in complex behaviours (e.g. foraging) or creations (e.g. a jet aeroplane). Bewildered by outcomes, we fail to grasp the significance of ongoing formation and transformation in the complexity we observe.

Life is transformation and throughout the process the functional integrity of the individual is the referent (Maturana \& Varela, 1980), but the referent changes constantly. This recurrent dynamic begins at conception and ends with death, itself yet another transformation. At conception, the fertilized ovum begins changes that continue throughout life (Provenza \& Balph, 1988, 1990; Provenza, 1995, 1996; Piersma \& Lindstrom, 1997): neural activity (Coppersmith \& Leon, 1984; Freeman, 1991), visceral mass (Distel \& Provenza, 1991; Ortega-Reyes \& Provenza, 1993), and physiological responses (Mehansho et al. 1983; Cheeke, 1998) are examples of morphological and physiological processes that change constantly.

\section{Physical environments: the only constant is change}

The universe is a self-organizing system. Its dynamic nature is a function of the constant exchange of energy and matter among structures as massive as galaxies and as minuscule as 
subatomic particles. Just $10^{-43}$ seconds before the Big Bang, the density of the universe was infinite, time and space were united and the universe behaved in a random, capricious, chaotic manner because time and space did not exist as separate entities (Kaufmann, 1994). Minute fluctuations in density and temperature that existed 300000 years after the Big Bang (the universe was one thousandth of 1 percent hotter in some areas than others) have been amplified over time to create the present day universe (Morris, 1993). Without these seemingly trivial differences in density and temperature, the universe would be nothing but diffuse gas. Conversely, greater densities and temperatures would have led to structures much larger than those in the present day universe. The notion of a dynamic universe is not new. Hindu sages pictured the universe as periodically expanding and contracting and gave the name kalpa to the unimaginable time between the beginning and end of a creation. The idea of a periodically expanding and contracting universe also arose in ancient Indian mythology: Lila is a rhythmic play which goes on in endless cycles, the one becoming the many and the many returning into the one (Capra, 1991). If the evolutionary tape were rewound and played again, one would surely get different results (Gould, 1989; Dennett, 1995).

Earth has been in transformation since a cloud of interstellar gas and dust contracted under the force of its own gravity to form the sun, the earth, and the other planets (Kaufmann, 1994). Earth's rocky exterior is divided into enormous plates that scour against one another, causing the continents to float on the somewhat pliable mantle below, creating mountain ranges, volcanos, earthquakes, and oceanic trenches. Earth's flora and fauna are a diverse mix of millions of species that traverse a range of environments, from ocean floors to mountaintops, from polar caps to deserts. Just as continents drift on the mantle below, plants and animals move on the surface above (Johnson \& Mayeux, 1992; Tausch et al. 1993; Wu \& Loucks, 1995). In Western North America, stipoid grasses that evolved during the Pliocene with horses, antelope-like grazers, giant bison, and camels were replaced during the Pleistocene with bluestems, indian grass, grama grass, and buffalograss east of the Rocky Mountains, and by needlegrass, ricegrass, and wheatgrasses west of the Rocky Mountains; horses, antelope-like grazers, giant bison, and camels that foraged in North America during the Pliocene, moved to South America during the Pleistocene, and as the glaciers retreated late in the Pleistocene most of the now extinct megafauna was replaced with bison, elk, deer, sheep, goats, and pronghorn (Stebbins, 1981).

Changes in physical environments alter the distribution, abundance, nutritional, and toxicological characteristics of plants. Resource availability (i.e. moisture, sunlight) affects soil fertility which in turn affects the evolution of mechanisms plants possess that deter herbivory (Bryant et al. 1983; Coley et al. 1985). Resource-rich environments are characterized by nutritious plant species low in metabolites that deter feeding by herbivores, whereas resourcepoor environments are characterized by plant species high in compounds (tannins, terpenoids, alkaloids, cyanogenic glycosides) that often deter feeding. Soil moisture, fertility, and sunlight affect the nutrient and toxin concentrations in plants (Bryant et al. 1983, 1991, 1992; Hobbs, 1996). Plant chemistry also changes, even within the day, as plants grow and mature. Cattle, sheep, and goats prefer tall fescue and lucerne (alfalfa) harvested in the afternoon to that harvested in the morning, evidently because of higher soluble carbohydrate concentrations (Fisher et al. 1997a,b).

Environmental perturbations-drought, fire-affect plants in ways that are difficult to predict. Nutrient and toxin concentrations change dynamically and nonlinearly in tomatoes subjected to increasing drought stress; depending on a tomato plant's response, many possible effects on herbivores can occur, some of them complex and nonlinear (English-Loeb et al. 1997). Physical (sunlight, soil moisture and nutrients) and biological (past herbivory) influences 
on plant chemistry help explain why even conspecific herbivores vary in their preferences for plants of the same species growing under different conditions.

Selective foraging by herbivores in turn can increase or decrease concentrations of nutrients and toxins in plants (Bryant et al. 1983, 1991, 1992), and it can create spatial heterogeneity by altering rates of nutrient cycling, plant productivity, and fire regimes (Hobbs, 1996). The effects of herbivores on plants depend on a variety of factors (number of animals, abundance of different plant species, amount of use of different plant species, prevailing environmental conditions) that vary over days, seasons, and years and make the outcomes of plantherbivore interactions difficult to predict.

The effects of herbivores on plants also depend on intraspecific variation among animals, which is partly influenced by morphological and physiological differences among individuals. Variations in dental arcade affect the foraging abilities of individual sheep and goats (Gordon et al. 1996), as do differences in organ mass and how animals metabolize macronutrients (Konarzewski \& Diamond, 1994). Lambs of uniform age, sex, and breed vary in their preferences for foods. Some lambs prefer foods high in energy, whereas others prefer foods of medium or even low energy (Provenza et al. 1996; Scott \& Provenza, 1998). Doses of sodium propionate (sodium and energy) that condition preferences in some lambs condition aversions in others (Villalba \& Provenza, 1996). Responses to toxins also vary (Provenza et al. 1992). Some sheep fed a high level of Galega officinalis failed to show any symptoms of toxicosis, whereas others were killed by a low dose (Keeler et al. 1988). Sheep show similar variation in susceptibility to Verbesina encelioides (Keeler et al. 1992), as do goats to condensed tannins in Coleogyne ramosissima (Provenza et al. 1990). Thus, morphological and physiological factors influence food and habitat preferences as individuals interact with physical and social environments.

\section{Social environments: from novelty to familiarity}

Life exists at the edge of chaos, ever clinging to its current form, forever challenged to change forms. The image of life poised at the boundary between order and chaos is epitomized by the dichotomy between the familiar (known, orderly, predictable) and the unfamiliar (unknown, unorderly, unpredictable). The transition from unfamiliar to familiar begins at conception with mother, and continues after birth with mother and peers. Social interactions early in life lead to familiar/novel dichotomies, which are manifest behaviourally in various ways: animals prefer familiar to novel foods and environments and they prefer to be with companions as opposed to strangers. Wariness of the unfamiliar is often attributed to innate abilities to discern-for instance, the innate tendency to fear snakes (Wilson, 1998)-but in suggesting that animals innately know something is harmful or beneficial, we overlook how essential it is for survival that animals show cautious regard for anything novel (different), until its attributes can be discerned. Transitions from the familiar to the unfamiliar become increasingly unlikely, especially as animals age, but they are nonetheless inevitable, a result of fluctuations and perturbations that occur throughout life, within animals and across social and physical environments.

For much of the human population, the ingestion of food is a relatively safe endeavor. Grocery stores stock nutritious foods, and there is little concern about buying items that may be toxic. Unlike humans, herbivores depend on their ability to discriminate nutritious from toxic foods. The first step in discriminating among novel foods is taken with the aid of mother. Anyone who has reared an animal from birth (be that a duck, lamb, dolphin, or bear) and 
compared its behaviour with conspecifics reared by mother realizes the profound influence of early experience on behaviour. Experiences in utero and with mother's milk help mammals to become familiar with the foods that mother eats before and just after birth (Nolte \& Provenza, 1991; Nolte et al. 1992). Interactions with mother (Mirza \& Provenza, 1990, 1992) and peers (Provenza \& Burritt, 1991; Biquand \& Biquand-Guyot 1992; Ralphs, 1997), combined with the consequences of food ingestion (Flores et al. 1989; Provenza et al. 1993a; Ortega-Reyes \& Provenza, 1993), help young animals to discriminate among foods and to forage efficiently.

\section{Conditions adequate: familiarity breeds content, novelty breeds contempt}

When nutritional and physiological conditions are adequate, animals eat small amounts of novel foods (i.e. they are neophobic) (Provenza et al. 1995). For instance, lambs fed a basal diet adequate in macronutrients less readily ingest novel foods high in protein or energy than do lambs fed a basal diet low in either protein or energy (Wang \& Provenza, 1996a). Similarly, cattle and sheep range more extensively in the late dry season than in the early-and mid-wet seasons, when food supplies are abundant and of high nutritional quality (Dudziński et al. 1978, 1982). Well fed animals gradually increase intake of novel foods, provided the foods are nutritious (Andelt et al. 1992; Provenza et al. 1995). Young animals are neophobic, even while foraging with mother (Provenza et al. 1993a), but they are somewhat less neophobic than older animals (Squibb et al. 1990; Thorhallsdottir et al. 1990). Cautious ingestion of novel foods helps herbivores survive in a world where the nutritional and toxicological characteristics of forages change constantly (Freeland \& Janzen, 1974; Provenza \& Balph, 1990; for reasons why herbivores inadvertently overingest toxic foods see Provenza et al. 1992; Provenza, 1997).

Preference for familiar over novel foods is evident when toxicosis follows a meal. When animals consume familiar and novel foods in a meal, and subsequently experience toxicosis, they avoid the novel foods-not the familiar foods-in ensuing meals (Burritt \& Provenza, 1989, 1991; Provenza et al. 1993a). When they become ill after a meal of novel foods, they avoid the foods whose flavours are most novel (Kalat, 1974; Burritt \& Provenza, 1989; Launchbaugh et al. 1993; Provenza et al. 1994a). When offered foods in sequence, animals avoid the food eaten just prior to illness (Provenza et al. 1993b), unless one of the foods is novel, in which case they avoid the novel food (Revusky \& Bedarf, 1967).

Preference for the familiar over the novel is also evident as individuals interact with social and physical environments. Many species of herbivores occur in subgroups of familiar individuals (companions) who show fidelity to particular home ranges (e.g. sheep, Hunter \& Milner, 1963; moose, Andersen, 1991; cattle, Howery et al. 1996; white-tailed deer, McNulty et al. 1997). Sheep and deer prefer to forage with companions as opposed to strangers in locations containing preferred foods. When subgroups of sheep who differ in food preferences forage in areas where preferred foods are distributed in scattered patches, those who are not related or who have not been reared together typically forage in different locations (Key \& MacIver, 1980; Scott et al. 1995, 1996). The most dramatic declines in intake occur when animals in novel environments are offered novel foods (Burritt \& Provenza, 1997). Sheep in unfamiliar environments prefer familiar to novel foods (Gluesing \& Balph, 1980), even if the familiar foods have previously caused toxicosis (Burritt \& Provenza, 1997).

Mother, peers, and drought all influence home ranges as calves mature to adults. Individuals prefer the home range of their mother, but interactions with peers and drought affect preferences and influence cattle to move at least temporarily to unfamiliar locations (Howery et al. 1998). Animals in unfamiliar environments often walk farther, ingest less food, and suffer 
more from malnutrition and toxicity than animals in familiar environments (Griffith et al. 1989; Provenza \& Balph, 1990). In an unfamiliar environment, naive sheep may stray as far as $150 \mathrm{~km}$ from the experienced herd's normal range, evidently in search of familiar foods and habitats (Warren \& Mysterud, 1993). Despite such hazards, animals make the transition to the unfamiliar in search of food, water, and mates owing to fluctuations and perturbations within animals and across social and physical environments.

\section{Conditions inadequate: familiarity breeds contempt, novelty breeds content}

When nutritional and physiological conditions are inadequate, animals more readily ingest novel foods (i.e., they become neophyllic). The tendency to explore options that may or may not pay off is higher in animals that are nutritionally deficient than in animals that are meeting their nutritional needs (Caraco et al. 1990). Ruminants experiencing nutrient deficits ingest novel foods, including items that well fed animals avoid (reviewed in Provenza, 1995). Cattle with mineral deficiencies eat rabbit flesh and bones, which nondeficient animals avoid (Wallis de Vries, 1994). Deer and other ungulates experiencing deficits eat antlers (Sutcliffe, 1977). Angora goats foraging on nitrogen-deficient blackbrush pastures ingest woodrat houses high in nitrogen (Provenza, 1977), and bighorn sheep use rodent middens as mineral licks (Coates et al. 1991). Ruminants experiencing deficiencies consume live and dead lemmings, rabbits, birds (caribou, red deer, sheep: Kelsall 1968; J.P. Bryant, pers. comm.; Furness, 1988), ptarmigan eggs (caribou: D. Swanson, personal communication), arctic tems (sheep), and fish (whitetailed deer: Bazely, 1989). Cattle ingesting mineral deficient forages lick urine patches of rabbits and man, chew wood, consume soil, eat faecal pellets of rabbits, and ingest nonfood items such as plastic, feathers, bones, cinders, sacks, and tins (Green, 1925).

\section{Individual experience: integration of the senses and the body}

\section{A functional explanation for palatability}

Palatability is typically defined as pleasant or acceptable to the taste and hence fit to be eaten or drunk. This definition highlights the role of taste, but ignores the role of postingestive feedback. Accenting only taste recreates what Damasio (1994) coined as 'Descartes' Error', which is the disarticulation of the CNS from the body.

Palatability is best understood as the interrelationship between the senses and postingestive feedback, as influenced by an animal's physiological condition and a food's chemical characteristics (Provenza, 1995, 1996). Taste and smell enable animals to discriminate among foods and provide hedonic sensations associated with eating. Postingestive feedback calibrates hedonic sensations from taste and smell commensurate with a food's homeostatic utility.

Palatability increases, even for poorly nutritious foods like straw and grape pomace, when ingestion of those foods is paired with intragastric infusions of energy and protein (sheep: Burritt \& Provenza, 1992; Villalba \& Provenza, 1996; 1997a,b,c; rats: Sclafani, 1996). Conversely, palatability decreases, even of foods rich in energy and protein, when ingestion is paired with intragastric infusions of toxins (sheep: Provenza, 1995, 1996; rats, Garcia, 1989); the decrease depends on the dose of the toxin (du Toit et al. 1991). Animals typically limit intake of toxin-containing nutritious foods to the amount of a particular toxin they can detoxify, the level of toxin satiation (Freeland \& Janzen, 1974; McArthur et al. 1991; Launchbaugh et al. 
1993). When macronutrient and toxin concentrations vary in foods, herbivores (Wang \& Provenza, 1996b, 1997) and omnivores (Kimball, 1997) prefer foods high in macronutrients and low in toxins, regardless of the flavour (Wang \& Provenza, 1997) or the physical characteristics (Villalba \& Provenza, 1998c).

\section{Preference depends on nutritional state}

Food preference is influenced by palatability and both depend on an animal's current nutritional state. Sucrose and glucose taste pleasant to fasted humans, but become unpleasant after they are consumed (Cabanac, 1971). People given flavoured, medium- and low-carbohydrate snacks prefer the flavour paired with low-carbohydrate snacks when satiated but not when food deprived (Booth \& Toase, 1983). Intravenous infusions of glucose reduce responsiveness to glucose by gustatory neurons that project to the nucleus tractus solitarius (NTS) (Scott, 1990). The reduction in afferent taste activity after a meal high in energy increases the likelihood that an animal will stop eating, and the response is strongest when both gustatory and visceral neurons are stimulated (Perez et al. 1996).

Preferences conditioned with protein and energy also depend on the nutritional state of insects (Simpson \& Raubenheimer, 1993), rodents (Gibson \& Booth, 1986, 1989; Ramirez, 1997), and ruminants (Cooper et al. 1993; Kyriazakis \& Oldham, 1993; Kyriazakis et al. 1994; Villalba \& Provenza, 1998a,c). Preference for food high in energy (protein) increases after a meal high in protein (energy) (Perez et al.; Berteaux et al. 1998; 1996; Villalba \& Provenza, $1998 a, c)$. Lambs maintain a relatively constant ratio of energy to protein in their diets, when they can select from foods varying in macronutrients (Egan, 1980; Provenza et al. 1996; Wang \& Provenza, 1996a), by discriminating between feedback signals from energy and protein (Villalba \& Provenza, 1998a). The synchrony of energy and protein fermentation also influences preference (Kyriazakis \& Oldham, 1997; Early \& Provenza, 1998).

Mineral needs also influence preference. Sheep strongly prefer flavoured straw alone to flavoured straw paired with gavage of $\mathrm{NaCl}$ when their mineral needs are met (Villalba \& Provenza, 1996). Thus, an animal's nutritional state influences food preference (Provenza, 1995, 1996).

\section{Neural integration of the senses and the body}

The neural integration of the senses (taste, smell) and postingestive consequences of food ingestion influence preference. The senses interact with the body through neurophysiological feedback loops (Garcia, 1989; Scott, 1990; Provenza, 1995). Nutrients and toxins influence organs and glands in the body and the CNS along vagal and splanchnic afferent nerves, and then proceed back to the body along efferent nerves to complete the feedback loop (Garcia et al. 1985; Garcia, 1989; Provenza, 1995). Afferent nerves for taste converge with visceral afferent nerves in the NTS of the brain stem. Taste and visceral afferent nerves from these structures proceed to the limbic system (thalamus, hypothalamus, amygdaloid complex, hippocampus) and from the limbic system to the cortex and back to the NTS (Barber \& Burks, 1987; Ricardo \& Koh, 1978). Besides influencing the activity of hypothalamic centres, the NTS is affected by the hypothalamus (Yuan \& Barber, 1992). Efferent impulses, from the CNS to effector organs, travel through the hypoglossal, glossopharyngeal, and trigeminal nerves (innervating the buccal cavity and pharynx), through the vagal nerve (innervating the pharynx, respiratory, and gastrointestinal tracts), from the respiratory centre to the phrenic and inter- 
costal nerves, and through some sympathetic efferent nerves in the gastrointestinal tract (Seynaeve et al. 1991). Clearly, the CNS is interconnected with the body and both are influenced by feedback mechanisms.

The interaction of central and enteric systems leads to self-organization in which simple rules change behaviour without the need to invoke high level goals. For instance, sensors in the liver apparently detect changes in cellular energy production (Friedman, 1997), which feeds back to taste afferents in the CNS - simple rule: as energy production changes, receptor activity changes. Neural activity evoked by taste and viscera also changes as the nutritional quality of food changes-simple rule: neural activity changes in accord with a food's energy concentration, which changes preference for taste.

Neural signals and physiological responses exhibit thresholds and nonlinearities, even when behaviours appear repetitive and cyclical (Kaplan \& Kaplan, 1991; Phillips \& Powley, 1996). Within olfactory processes, neurons signal the identity of familiar and novel odours via patterns of electrical bursts across the olfactory cortex (Freeman, 1991). When an animal is at rest, neural activity in the olfactory system appears unordered and chaotic. When exposed to a familiar odour, olfactory activity patterns are ordered and consistent. Novel odours change neural patterns, indicating that cortical activity is influenced by ongoing experiences. For instance, neural patterns are consistent when rabbits are exposed to sawdust, a familiar odour. But after rabbits learn to recognize the smell of banana, a novel odour, re-exposure to sawdust leads to a new pattern when rabbits again smell sawdust (Freeman, 1991). Interactions with the environment change patterns of firing (Solé et al. 1993). Thus, self-organization leads to complex, highly organized, and dynamic behaviours without a need to invoke high level goals or global knowledge.

\section{Leaming actively or passively}

Do animals actively seek occasions to learn about nutrient and toxin concentrations in familiar foods and to identify novel foods? Day et al. (1998) claim that "it is often proposed that animals learn about the nutritional qualities of their food resource during ongoing feeding behaviour (Provenza, 1995). However, an explanation based on [sic] passive information gathering is diametrically opposed to the possibility that animals may actively seek opportunities in which useful learning can occur". The proposal that animals learn actively (i.e. eat to learn), rather than passively (i.e. learn while they eat), cannot be falsified by experimentation. We believe that animals interact with their environment no more actively or passively than they labour to evolve or the sun works to heat the earth. Foraging behaviour does not depend on active or passive interactions; it is simply a response that maintains functioning.

The terms 'active' and 'passive' are labels, they are not functional accounts of ongoing processes. When cells lack nutrients, peripheral signals coordinated by the liver interact via vagal afferent nerves with the brain stem, limbic system, and higher cortical centres in the CNS to influence foraging behaviour (Provenza, 1995). Changes in food preference in response to postingestive feedback from nutrients and toxins occur automatically (as does digestion) without active learning. Postingestive feedback occurs while an animal is deeply anaesthetized, tranquilized, or when its electrocortical activity is depressed (digestion and absorption occur slowly, often while an animal sleeps) (Garcia, 1989). The nature of taste-feedback interactions is the reason preference changes despite knowledge of the cause of the feedback event. For instance, people acquire aversions to foods eaten prior to becoming ill (flu, seasickness, 
chemotherapy) even though they know the food was not responsible. Describing taste-feedback interactions as passive does not enhance understanding of the processes.

\section{Meeting foraging challenges: discriminating among foods}

The ability to discriminate familiar from novel foods, as discussed in relation to social interactions and palatability, and to discriminate among familiar or novel foods, depends on the functional integration of the senses and the body. Discrimination and generalization are critical for survival, and all problems with poisonous plants are due to an inability to discriminate or a lack of alternatives (Provenza, 1997).

Common ringtail and brushtail opossums discriminate among Eucalyptus leaves and trees based on concentrations of terpenes (1,8-cineole), which are highly correlated with jensenone, a compound that is aversive to opossums (Lawler et al. 1998). Wild opossums show a dose dependent reduction in intake when 1,8-cineole is added to their food, but they increase intake of the nutritious food containing 1,8-cineole with continued exposure when the food lacks jensenone. Thus, opossums discriminate among familiar foods based on the flavour of terpenes and the postingestive effects of jensenone.

Animals also discriminate based on changes in flavour. Lambs immediately reduce intake of a familiar food, rice, when it contains a novel flavour, onion. Similarly, sheep routinely fed elm from one location would not eat elm of the same species taken from another site, evidently because the smell and taste of elm differed from the two locations (Provenza et al. 1993a). Immediate reductions in intake of familiar foods with novel flavours reduces the likelihood of overingesting toxins.

Goats and sheep discriminate among novel foods based on flavour concentration, and they typically avoid flavour concentrations that are most different from what they have eaten in the past. Current season's growth (CSG) and older growth (OG) twigs from the shrub blackbrush share a common flavour, but the flavour is stronger in CSG. When goats first eat a meal of CSG and OG and then experience toxicosis, they subsequently avoid CSG (Provenza et al. 1994a). Sheep (Launchbaugh et al. 1993) also avoid foods with high concentrations of flavours because they are most novel. When lambs familiar with unflavoured barley are offered flavoured barley with a low or a high concentration of an added flavour, in separate food boxes, and then receive a mild dose of toxin, they subsequently avoid the barley with the highest flavour concentration, regardless of whether the flavour is bitter (alum) or sweet (saccharin) (Launchbaugh et al. 1993). Rats that receive flavoured (familiar) and unflavoured (unfamiliar) food followed by toxicosis avoid the unflavoured food because it is most different (Kalat \& Rozin, 1970; Kalat, 1974).

The amount of food ingested and the novelty of a food's flavour interact with the food's postingestive effects to enable animals to discriminate among foods within a meal. Following toxicosis, goats naive to blackbrush avoid the plant part, CSG or OG, they ate in the greatest amount (Provenza et al. 1994a). After drinking solutions of different flavours and experiencing toxicosis, rats also acquire aversions to the flavour consumed in the largest amount (Bond \& Di Giusto, 1975).

Sheep must ingest a threshold amount of a novel food in order to discriminate among foods, and an animal's nutritional state influences the response. Sheep exposed to novel foods

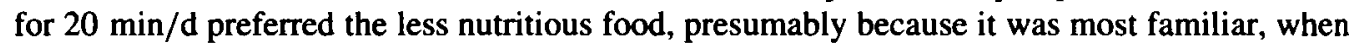
they ingested a basal diet containing adequate macronutrients. However, the lambs quickly preferred the most nutritious food when offered only the novel foods for $8 \mathrm{~h} / \mathrm{d}$ (Villalba \& 
Provenza, 1998b). Thus, lambs discriminate based on both nutritional state and amount of food eaten, factors that undoubtedly influence preferences as food nutritional qualities, toxicities, and abundances change daily and seasonally.

Rapid flavour-feedback interactions help ruminants discriminate among foods. Postingestive feedback is greater and more rapid with nutritious, highly digestible foods (Provenza, 1995). Rapid feedback creates a positive feedback loop that increases preference. The more food ingested, the greater the feedback. Levels of portal and jugular blood metabolites (e.g. volatile fatty acids, ammonia) increase within 15 min after ruminants begin to eat nutritious foods (Evans et al. 1975; Chase et al. 1977; de Jong, 1981; Van Soest, 1994), and chemoreceptors respond within seconds to nutrients in the gastrointestinal tract (Leek, 1977; Cottrell \& Iggo, 1984; Mei, 1985). The converse is also true. The lack of rapid feedback from poorly nutritious foods quickly decreases preference.

The ability to generalize based on past experience also helps animals to quickly identify potentially toxic, novel foods. Animals generalize aversions from past experiences, thus reducing the risks associated with toxic novel foods or familiar foods whose flavours have changed. When lambs eat cinnamon-flavoured rice and then experience toxicosis, their preference for cinnamon-flavoured rice declines. When they are subsequently offered wheat, which they prefer, but with cinnamon flavour added, they refuse to eat it. Thus, lambs generalize an aversion from rice to wheat based on a common flavour, cinnamon (Launchbaugh \& Provenza, 1993).

Sheep and goats similarly generalize preferences. Lambs that have eaten cereal grains (milo, barley, wheat), which are $\sim 80 \%$ starch, subsequently prefer novel foods (e.g. grape pomace with added starch) high in starch (Villalba \& Provenza, 1998b). Sheep and goats also prefer hay sprayed with extracts of preferred high grain concentrates (Dohi \& Yamada, 1997), and sheep more readily ingest novel foods (e.g. rice bran) sprayed with extracts from familiar foods (e.g. grass) (Tien et al. 1998).

Animals also generalize across broad classes of experience. Lambs that experience toxicosis, even if that occurred only once after they ate a novel food, become increasingly reluctant to eat any novel food (F. D. Provenza, unpublished data). Conversely, lambs that experience positive nutritional consequences every time they eat a novel food more readily consume any novel food (Launchbaugh et al. 1997).

Discriminations and generalizations are virtually impossible to recognize unless one knows an animal's history. For instance, nutrient-induced food preferences, which may have occurred as a result of exposure to a food several years ago (Green et al. 1984), cause some animals (experienced) to readily eat a food that other animals (naive) avoid (Provenza et al. 1995). The same is true of aversions. Food aversions gradually cease, if toxicosis is absent. If, after an aversion has ceased, a lamb eats a meal of familiar foods, one of which previously made it ill, and then experiences toxicosis, the lamb will subsequently avoid the food that made it ill, not the other familiar foods (Burritt \& Provenza, 1996).

\section{Varied diets: from chaos to order}

Herbivores eat a variety of foods. Some contend that information gathering, a high level goal arising from intrinsic and extrinsic motivation, causes animals to sample a variety of foods and helps them to appraise the nutritional value of different foods (Day et al. 1998). The conventional foraging goal, to maximize nutrient intake per unit effort, is assumed to be equivalent 
to fitness maximization (number of offspring produced). Thus, the rate of energy intake is often used as the currency of foraging.

Nevertheless, there is little evidence that herbivores select diets that maximize rates of intake. Herbivores forage at rates lower than their potential (Owen-Smith, 1993; O'Reagain et al. 1996), forage in less profitable food patches than predicted (Langvatn \& Hanley, 1993; Wilmshurst et al. 1995; van Wieren, 1996), overuse poorer sites and underuse richer sites (reviewed by Kennedy \& Gray, 1993), and do not maximize intake rate when patch quality is uncertain (Kamil et al. 1993). Illius \& Hodgson (1996) note that "Although intake rate maximization is assumed to apply in teleonomic models of mammalian herbivore foraging there is little direct evidence that herbivores select diets which do actually maximize intake rate ... Amongst the few reports of animals selecting diets which maximized intake rate are those of Black \& Kenney (1984) and Demment et al. (1993), and in neither case is the evidence particularly striking. More often, herbivore diets are characterized by the diversity of constituents-that is, they contain a mixture of food items with apparent disregard for the intake rate each offers."

Some believe that this variety reduces the likelihood of overingesting toxins (Freeland \& Janzen, 1974). They hypothesize that toxins limit the amount of the food that an animal can tolerate. To ingest needed macronutrients, animals consume small amounts of a variety of foods that contain a variety of toxins which may be detoxified by different mechanisms. Others believe that animals eat a variety of foods in order to meet nutritional needs (Westoby, 1978). According to this hypothesis, no single food contains the proper mix of macronutrients, minerals, and vitamins needed by an animal. Therefore, to balance their diet, animals must eat a variety of foods. Both of these theories are inconsistent with herbivores' consumption of an assortment of foods, even when toxins are not a concern and nutritional needs are met by one or a few food sources. Lambs (Provenza et al. 1996; Early \& Provenza, 1998), red deer (Langvatn \& Hanley, 1993), and wapiti (Wilmshurst et al. 1995) eat several nutritious (and nontoxic) foods, even when one food best meets their needs.

\section{Exceeding sensory-, nutrient-, and toxin-specific thresholds}

We explain varied diets by mechanisms that encompass the acquisition of nutrients and the avoidance of toxins (Provenza, 1996). Interactions between the senses and the body explain why animals change food preferences, within meals and from meal to meal. Sensory receptors respond to gustatory (i.e. sweet, salt, sour, bitter), olfactory (i.e. a diversity of odours), and tactile (e.g. astringency, pain) stimuli. These receptors then interact with visceral receptors that respond to nutrients and toxins (chemoreceptors), osmolality (osmoreceptors), and distension (mechanoreceptors). These processes affect preference. The degree of neural activation sets limits. Within these limits, preference increases when foods contain needed macronutrients (Villalba \& Provenza, 1996, 1997a,b,c, 1998a). When limits are exceeded, excesses and deficits of nutrients and excesses of toxins reduce preferences (Provenza, 1995). Responses to nutrients (Villalba \& Provenza, 1996, 1997a,b,c) and toxins (du Toit et al. 1991) operate along a continuum from preference to aversion, depending on the frequency and intensity of stimulation (Provenza, 1995, 1996). Cyclic patterns of intake of a variety of foods reflect seemingly chaotic interactions among flavours, nutrients, and toxins interacting along continua (Pfister $e t$ al. 1997; Atwood \& F.D. Provenza, unpublished). These tolerance ranges and limits are the rules governing food preferences. 
A key concept in our hypothesis regarding varied diets is aversion, defined as the decrease in amount of familiar foods consumed as a result of nearing or exceeding tolerance limits for sensory (smell, taste, texture, i.e. flavour) and postingestive (effects of nutrients and toxins on chemo-, osmo-, and mechano-receptors) effects (Provenza, 1996). After eating any food too frequently or excessively, animals will be more likely to eat alternative foods owing to exceeding tolerance limits. Aversions may be pronounced when foods contain toxins or excessive levels of rapidly digestible nutrients (e.g. some forms of nitrogen and energy); they also occur when foods are deficient in specific nutrients; aversions occur even when animals eat nutritionally adequate foods because satiety and surfeit are on a continuum. Any food may cause a mild aversion, as can too frequent consumption or consumption in excess. Animals still have basic preferences for foods, but they experience transient decreases in preference, even for highly nutritious foods. Animals fed nutritionally balanced food in one of two flavours for $1 \mathrm{~d}$ prefer the alternative flavour in 30 -min tests ( $2 \mathrm{~d}$ persistence); the decrease in preference is more persistent when a food is either deficient ( $4 \mathrm{~d}$ persistence) or excessive ( $>6 \mathrm{~d}$ persistence) in macronutrients (sheep: Early \& Provenza, 1998; cattle: Atwood \& F.D. Provenza, unpublished). Flavour affects preference less than macronutrients or toxins (Provenza et al. 1996; Wang \& Provenza, 1997; Early \& Provenza, 1998).

Sensory-specific satiety has been shown to be partly responsible for changes in food preference during a meal (Rolls et al. 1984; Rolls, 1986a; Swithers \& Hall, 1994). It induces higher food intakes and weight gains when rats are offered high energy diets in a variety of flavours; an animal that stops eating one food will often immediately consume as many calories again from another food (Naim et al. 1986). The decreases in preference from sensory-specific satiety occur with foods of different nutritional values (Birch \& Deysher, 1986), with nutritive or nonnutritive flavours (Wooley et al. 1972; Swithers-Mulvey et al. 1991), and with the sweetest sodas, even when they are tasted and not swallowed (Drewnowski et al. 1982). This partly reflects the reduced activity of afferent nerves for taste (Rolls, 1986b; Scott, 1990). Preference changes most when animals are provided with both gustatory and visceral stimulation (Perez et al. 1996). Thus, taste and postingestive feedback interact to change preference for and intake of a variety of foods (Cabanac, 1971; Provenza, 1996).

\section{Aversions yield benefits that are mistaken as causes of varied diets}

Benefits of aversions (to induce sampling of foods, obtain a balanced diet, reduce ingestion of toxic foods, or maintain a diverse microflora in the gut) are often mistaken as the cause of varied diets. Herbivores are probably even less cognizant than most humans of their specific physiological requirements, concentrations of nutrients or toxins in plants, or microflora in their gut. Thus, it is inconceivable that they forage to sample foods, procure a balanced diet, avoid toxic foods, or create a diverse microflora in their gut. Rather, these behaviours are natural outcomes of automatically responding to physiological and biochemical signals. These sensory-, nutrient-, and toxin-specific signals function in a noncognitive manner (Provenza et al. 1994b). Responses occur along a continuum at all levels within the body, for nutrients (Villalba \& Provenza, 1996, 1997a,b,c) and toxins (du Toit et al. 1991). Responses depend on the frequency and intensity of stimulation of neural receptors (Provenza, 1995, 1996). The strength of neuronal signals depends on the kinds and amounts of neurotransmitters released at synapses and how long they remain in synaptic clefts (Provenza, 1995). Changes in concentrations of nutrients and toxins affect patterns of neural firing, which in turn change behaviour. So-called foraging goals are simply labels used by humans, just as nutritional wisdom is a label for the 
observation that animals eat mostly what is good for them. They are not functional accounts of behaviour.

\section{Conclusions}

We differ philosophically and pragmatically from those who think high level goals explain complex behaviours (Day et al. 1998). Animals respond to changes in nutrient and toxin concentrations in familiar foods, and identify new foods, without intrinsic and extrinsic motivation or inferred high level goals. The ability to discriminate familiar from novel foods and to discriminate among familiar or novel foods, as discussed in relation to social interactions, palatability, discrimination, and generalization, depends on the functional integration of the senses and the body. Palatability is the functional integration of the senses (smell, taste, texture) and postingestive feedback (effects of nutrients and toxins on chemo-, osmo-, and mechano-receptors), as influenced by an animal's physiological condition and a food's chemical characteristics. Preference is influenced by palatability and both depend on an animal's current nutritional state. Animals eat a variety of foods as a result of nearing or exceeding tolerance limits for sensory and postingestive effects unique to each food. After eating any food too frequently or excessively, the likelihood increases that animals will eat alternative foods owing to exceeding sensory-, nutrient-, and toxin-specific tolerance limits. Cyclic patterns of intake of a variety of foods reflect seemingly chaotic interactions among flavours, nutrients, and toxins interacting along continua. Changes in the physical environment affect changes in the distribution, abundance, nutritional, and toxicological characteristics of foods. Ingestion of plants by herbivores affects the availability, nutritional and toxicological characteristics of residual plants, which in turn affects subsequent foraging behaviour.

According to this view, complex and dynamic behaviours arise from simple rules operating at levels of resolution from cells and organs to individuals and their interactions with social and physical environments (Figs 1, 2). At all these levels, the notion of cause and effect is replaced with functional relationships between behaviours and environmental consequences. Behaviour is a function of its consequences: a behaviour operating on the environment to induce changes is itself changed by those events. Thus, behaviour emerges from its own functioning, behaviour self-organizes, not from that of its surroundings. This ostensible autonomy notwithstanding, no self-organizing system (cell, organ, or individual) is independent of its environs because existence consists of an ongoing exchange of energy and matter. Within this abiding dialogue, there are no distinctions between antecedents and consequences, merely circular arrangements of functionally connected components. Hierarchies of organization and high level goals reflect the observer's logic, not the system's ongoing functioning, and constructions regarding causation are simply images of control that reflect the observer's framework of assumptions, as well as the restrictions imposed by observational methods (Kaplan \& Kaplan, 1991). Selforganizing systems exist and change as do their ongoing functioning, self-regulated by dynamic feedback loops, influenced by history, necessity, and chance (Prigogine \& Stengers, 1984). Existence is transformation, and the functional integrity of the system is the dynamic referent from birth to death, yet another transformation.

\section{References}

Andelt, W. F., Baker, D. L. \& Burnham, K. P. (1992). Relative preference of captive cow elk for repellent-treated diets. Journal of Wildlife Management 56, 164-173.

Andersen, R. (1991). Habitat deterioration and the migratory behaviour of moose (Alces alces L.) in Norway. Journal of Applied Ecology 28, 102-108. 
Aoki, C. \& Siekevitz, P. (1988). Plasticity in brain development. Scientific American 256(12), 56-64.

Barber, W. D. \& Burks, T. F. (1987). Brain-gut interactions: brain stem neuronal response to local gastric effects of substance P. American Joumal of Physiology 253, G369-G377.

Bazely, D. R. (1989). Camivorous herbivores: mineral nutrition and the balanced diet. Trends in Ecology and Evolution 4, 155-156.

Berteaux, D., Crete, M., Huot, J., Maltais, J. \& Ouellet, J.-P. (1998). Food choice by white-tailed deer in relation to protein and energy content of the diet: a field experiment. Oecologia 115, 84-92.

Biquand, S. \& Biquand-Guyot, V. (1992). The influence of peers, lineage and environment on food selection of the criollo goat (Capra hircus). Applied Animal Behaviour Science 34, 231-245.

Birch, L. L. \& Deysher, M. (1986). Caloric compensation and sensory specific satiety: evidence for self regulation of food intake by young children. Appetite 7, 323-331.

Black, J. L. \& Kenney, P. A. (1984). Factors affecting diet selection by sheep. II. Height and density of pasture. Australian Journal of Agricultural Research 35, 565-578.

Bonabeau, E., Theraulaz, G., Deneubourg, J. L., Aron, S. \& Camazine, S. (1997). Self-organization in social insects. TREE 12, 188-193.

Bond, N. \& Di Guisto, E. (1975). Amount of solution drunk is a factor in the establishment of taste aversion. Animal Learning and Behavior 3, 81-84.

Booth, D. A. \& Toase, A. M. (1983). Conditioning of hunger/satiety signals as well as flavour cues in dieters. Appetite 4, 235-236.

Brothers, L. (1997). Friday's Footprint. New York: Oxford University Press.

Bryant, J. P., Chapin, F. S. \& Klein, D. R. (1983). Carbon/nutrient balance of boreal plants in relation to vertebrate herbivory. Oikos 40, 357-368.

Bryant, J. P., Provenza, F. D., Pastor, J., Reichardt, P. B., Clausen, T. P. \& Du Toit, J. T. (1991). Interactions between woody plants and browsing mammals mediated by secondary metabolites. Annual Review of Ecology and Systematics 22, 431-446.

Bryant, J. P., Reichardt, P. B., Clausen, T. P., Provenza, F. D. \& Kuropat, P. J. (1992). Woody plant-mammal interactions. In Herbivores: their interactions with secondary plant metabolites. 2. Ecological and evolutionary processes, 2nd edn, pp. 343-370 [G. A. Rosenthal and M.R. Berenbaum, editors]. New York: Academic Press.

Burritt, E. A. \& Provenza, F. D. (1989). Food aversion learning: ability of lambs to distinguish safe from harmful foods. Joumal of Animal Science 67, 1732-1739.

Burritt, E. A. \& Provenza, F. D. (1991). Ability of lambs to learn with a delay between food ingestion and consequences given meals containing novel and familiar foods. Applied Animal Behaviour Science 32, 179-189.

Burritt, E. A. \& Provenza, F. D. (1992). Lambs form preferences for nonnutritive flavors paired with glucose. Journal of Animal Science 70, 1133-1136.

Burritt, E. A. \& Provenza, F. D. (1996). Amount of experience and prior illness affect the acquisition and persistence of conditioned food aversions in lambs. Applied Animal Behaviour Science 48, 73-80.

Burritt, E. A. \& Provenza, F. D. (1997). Effect of an unfamiliar location on the consumption of novel and familiar foods by sheep. Applied Animal Behaviour Science 54, 317-325.

Cabanac, M. (1971). Physiological role of pleasure. Science 173, 1103-1107.

Capra, F. (1991). The Tao of Physics. Boston, MA: Shambhala.

Capra, F. (1996). The Web of Life. New York: Doubleday.

Caraco, T., Blanckenhom, W. U., Gregory, G. M., Newman, J. A., Recer, G. M. \& Zwicker, S. M. (1990). Risksensitivity: ambient temperature affects foraging choice. Animal Behaviour 39, 338-345.

Chase, L. E., Wangsness, P. J., Kavanaugh, J. F., Griel, L. C. \& Gahagan J. H. (1977). Changes in portal blood metabolites and insulin with feeding steers twice daily. Joumal of Dairy Science 60, 403-409.

Cheeke, P. R. (1998). Natural Toxicants in Feeds, Forages, and Poisonous Plants. Danville IL: Interstate.

Cheney, C. D. (1994). The source and control of behavior. In Human Behavior in Today's World, pp. 73-86 [Waris Ishaq, editor]. New York: Praeger.

Chiesa, M. (1994). Radical Behaviorism: the philosophy and the science. Boston, MA: Authors Cooperative Inc.

Coates, K. P., Schemnitz S. D. \& Peters, J. T. (1991). Use of rodent middens as mineral licks by bighorn sheep. In Seventh Biennial Symposium, Northern Wild Sheep and Goat Council, pp. 206-209 [J. A. Bailey, editor]. Alberta: Northern Wild Sheep and Goat Council, Alberta Fish and Wildlife.

Cole, B. J. (1994). Chaos and behavior: the perspective of nonlinear dynamics. In Behavioral Mechanisms in Evolutionary Ecology, pp. 423-443 [L. A. Real, editor]. Chicago, IL: University of Chicago Press.

Coley, P. D., Bryant, J. P. \& Chapin, F. S. (1985). Resource availability and plant antiherbivore defense. Science 230, 895-899.

Cooper, S. D. B., Kyriazakis, I., Anderson, D. H. \& Oldham, J. D. (1993). The effect of physiological state (late pregnancy) on the diet selection of ewes. Animal Production 56, 469 (abstr.).

Coppersmith, R. \& Leon, M. (1984). Enhanced neural response to familiar olfactory cues. Science 225, 849-851.

Cottrell, D. F. \& Iggo, A. (1984). Mucosal enteroceptors with vagal afferent fibers in the proximal duodenum of sheep. Joumal of Physiology 354, 497-522.

Damasio, A. R. (1994). Descartes' Error: emotion, reason, and the human brain. New York: Avon Books.

Day, J. E. L., Kyriazakis, I. \& Rogers, P. J. (1998). Food choice and intake: towards a unifying framework of learning and feeding motivation. Nutrition Research Reviews 11, 25-43. 
De Jong, A. (1981). The effect of feed intake on nutrient and hormone levels in jugular and portal blood in goats. Journal of Agricultural Science 96, 643-657.

Demment, M. W., Distel, R. A., Griggs, T. C., Laca, E. A. \& Deo, G. P. (1993). Selective behaviour of cattle grazing ryegrass swards with horizontal heterogeneity in patch height and bulk density. In Proceedings, International Grassland Congress XVII, 712-714.

Dennett, D. (1995). Darwin's Dangerous Idea. New York: Norton.

Distel, R. A. \& Provenza, F. D. (1991). Experience early in life affects voluntary intake of blackbrush by goats. Joumal of Chemical Ecology 17, 431-450.

Dohi, H. \& Yamada, A. (1997). Preference of sheep and goats for extracts from high-grain concentrate. Journal of Animal Science 75, 2073-2077.

Drewnowski, A., Grinker, J. A. \& Hirsch, J. (1982). Obesity and flavor perception: multidimensional scaling of soft drinks. Appetite 3, 361-368.

Dudzinski, M. L., Müller, W. J., Low, W. A. \& Schuh, H.-J. (1982). Relationship between dispersion behaviour of freeranging cattle and forage conditions. Applied Animal Ethology 8, 225-241.

Dudzinski, M. L., Schuh, H.-J., Wilcox, D. G., Gardiner, H. G. \& Morrissey, J. G. (1978). Statistical and probabilistic estimators of forage conditions from grazing behaviour of merino sheep in a semi-arid environment. Applied Animal Ethology 4, 357-368.

du Toit, J. T., Provenza, F. D \& Nastis, A. S. (1991). Conditioned taste aversions: how sick must a ruminant get before it learns about toxicity in foods? Applied Animal Behaviour Science 30, 35-46.

Early, D. M. \& Provenza, F. D. (1998). Food flavor and nutritional characteristics alter dynamics of food preference in lambs. Journal of Animal Science 76, 728-734.

Egan, A. R. (1980). Host animal-rumen relationships. Proceedings of the Nutrition Society 39, $79-87$.

English-Loeb, G., Stout M. J. \& Duffey, S. S. (1997). Drought stress in tomatoes: changes in plant chemistry and potential nonlinear consequences for insect herbivores. Oikos 79, 456-468.

Evans, E. J., Buchanan-Smith, J. G. \& Macleod, G. K. (1975). Postprandial patterns of plasma glucose, insulin and volatile fatty acids in ruminants fed low- and high-roughage diets. Joumal of Animal Science 41, 1474-1479.

Fisher, D. S., Burns, J. C. \& Mayland, H. F. (1997a). Variation in preference for moming or afternoon harvested hay in sheep, goats, and cattle. Journal of Animal Science 75 (Suppl.), 201.

Fisher, D. S., Mayland, H. F. \& Bums, J. C. (1997b). Diumal timing of hay harvest and ruminant preferences for hays. Agronomy Abstracts p. 142.

Flores, E. R., Provenza F. D. \& Balph, D. F. (1989). Role of experience in the development of foraging skills of lambs browsing the shrub serviceberry. Applied Animal Behaviour Science 23, 271-278.

Freeland. W. J. \& Janzen, D. H. (1974). Strategies in herbivory by mammals: the role of plant secondary compounds. American Naturalist 108, 269-289.

Freeman, W. J. (1991). The physiology of perception. Scientific American 264(2), 78-85.

Friedman, M. I. (1997). An energy sensor for control of energy intake. Proceedings of the Nutrition Society 56, 41-50.

Furness, R. W. (1988). Predation on ground-nesting seabirds by island populations of red deer Cervus elaphus and sheep Ovis. Journal of Zoology 216, 565-573.

Garcia, J. (1989). Food for Tolman: cognition and cathexis in concert. In Aversion, Avoidance and Anxiety, pp. 45-85 [T. Archer and L. Nilsson, editors]. Hillsdale, NJ: Erlbaum.

Garcia, J., Lasiter, P. A., Bermudez-Rattoni, F. \& Deems, D. A. (1985). A general theory of aversion learning. In Experimental Assessments and Clinical Applications of Conditioned Food Aversions, pp. 8-21 [N.S. Braveman and P. Bronstein, editors]. New York: New York Academy of Sciences.

Gibson, E. L. \& Booth, D. A. (1986). Acquired protein appetite in rats: dependence on a protein-specific need state. Experientia 42, 1003-1004.

Gibson, E. L. \& Booth, D. A. (1989). Dependence of carbohydrate-conditioned flavor preference on intemal state in rats. Learning and Motivation 20, 36-47.

Glass, L., Beuter, A. \& Larocque, D. (1988). Time delays, oscillations, and chaos in physiological control systems. Mathematical Biosciences 90, 111-125.

Glass, L. \& Mackey, M. C. (1988). From Clocks to Chaos: the rhythms of life. Princeton, NJ: Princeton University Press.

Glass, L. \& Malta, C. P. (1990). Chaos in multi-looped negative feedback systems. Joumal of Theoretical Biology 145, 217-223.

Gluesing, E. A. \& Balph, D. F. (1980). An aspect of feeding behavior and its importance to grazing systems. Journal of Range Management 33, 426-427.

Gordon, I. J., Illius, A. W. \& Milne, J. D. (1996). Sources of variation in the foraging efficiency of grazing ruminants. Functional Ecology 10, 219-226.

Goss, S., Beckers, R., Deneubourg, J. L., Aron, S. \& Pasteels, J. M. (1990). How trail laying and trail following can solve foraging problems for ant colonies. In Behavioural Mechanisms of Food Selection (NATO ASI Series G: Ecological Sciences, vol. 20), pp. 661-677 [R.N. Hughes, editor.] Heidelberg: Springer-Verlag.

Gould, S. J. (1989). Wonderful Life: the Burgess Shale and the nature of history. New York: Norton.

Green, G. C., Elwin, R. L., Mottershead, B. E. \& Lynch, J. J. (1984). Long-term effects of early experience to supplementary feeding in sheep. Proceedings of the Australian Society of Animal Production 15, 373-375. 
Green, H. H. (1925). Perverted appetites. Physiological Reviews 5, 336-348.

Griffith, B., Scott, J. M., Carpenter, J. W. \& Reed, C. (1989). Translocation as a species conservation tool: status and strategy. Science $245,477-480$.

Hobbs, N. T. (1996). Modification of ecosystems by ungulates. Journal of Wildlife Management 60, 695-713.

Hollick, M. (1993). Self-organizing systems and environmental management. Environmental Management 17, $621-628$.

Howery, L. D., Provenza, F. D., Banner, R. E. \& Scott, C. B. (1996). Differences in home range and habitat use among individuals in a cattle herd. Applied Animal Behaviour Science 49, 305-320.

Howery, L. D., Provenza, F. D., Banner, R. E. \& Scott, C. B. (1998). Social and environmental factors influence cattle distribution on rangeland. Applied Animal Behaviour Science 55, 231-244.

Hunter, R. F. \& Milner, C. (1963). The behaviour of individual, related and groups of south country Cheviot hill sheep. Animal Behaviour 11, 507-513.

Illius, A. W. \& Hodgson, J. (1996). Progress in understanding the ecology and management of grazing systems. In The Ecology and Management of Grazing Systems, pp. 429-457 [J. Hodgson \& A.W. Illius, editors]. Wallingford: CAB International.

Johnson, H. B. \& Mayeux, H. S. (1992). Viewpoint: A view on species additions and deletions and the balance of nature. Journal of Range Management 45, 322-333.

Kalat, J. W. (1974). Taste salience depends on novelty, not concentration, in taste-aversion learning in the rat. Journal of Comparative and Physiological Psychology 86, 47-50.

Kalat, J. W. \& Rozin, P. (1970). 'Salience': A factor which can override temporal contiguity in taste-aversion learning. Journal of Comparative and Physiological Psychology 71, 192-197.

Kalil, R. E. (1989). Synapse formation in the developing brain. Scientific American 256 (12), 56-64.

Kamil, A. C., Misthal, R. L. \& Stephens, D. W. (1993). Failure of simple optimal foraging models to predict residence time when patch quality is uncertain. Behavioral Ecology 4, 350-363.

Kaplan, M. L. \& Kaplan, N. R. (1991). The self-organization of human psychological functioning. Behavioral Science 36, $161-178$.

Kauffman, S. (1995). At Home in the Universe: the search for laws of self-organization and complexity. London: Penguin Books.

Kaufmann, W. J. (1994). Universe, 4th edn. New York: W.H. Freeman and Company.

Keeler, R. F., Baker, D. C. \& Evans, J. O. (1988). Individual animal susceptibility and its relationship to induced adaption or tolerance in sheep to Galega officinalis. Letters in Veterinary and Human Toxicology 30, 420-423.

Keeler, R. F., Baker, D. C. \& Panter, K. E. (1992). Concentration of galegine in Verbesina encelioides and Galega officinalis and the toxic and pathologic effects induced by the plants. Journal of Environmental Pathology, Toxicology and Oncology 11, 75-81.

Kelsall, J. P. (1968). The Migratory Barren-Ground Caribou of Canada. Ottawa: Canadian Wildlife Service.

Kelso, J. A. (1995). Dynamic Patterns: the self-organization of brain and behavior. Cambridge, MA: MIT Press.

Kennedy, M. \& Gray, R. D. (1993). Can ecological theory predict the distribution of foraging animals? A critical analysis of experiments on the Ideal Free Distribution. Oikos 68, 158-166.

Key, C. \& Maclver, R. M. (1980). The effects of maternal influences on sheep: breed differences in grazing, resting and courtship behaviour. Applied Animal Ethology 6, 33-48.

Kimball, B. A. (1997). Chemical Ecology of Vascular Tissue Foraging by Black Bears. PhD thesis, Colorado State University.

Konarzewski, M. \& Diamond, J. (1994). Peak sustained metabolic rate and its individual variation in cold-stressed mice. Physiological Zoology 67, 1186-1212.

Kyriazakis, I. \& Oldham, J. D. (1993). Diet selection in sheep: the ability of growing lambs to select a diet that meets their crude protein (nitrogen $\times 6.25$ ) requirements. British Journal of Nutrition 69, 617-629.

Kyriazakis, I. \& Oldham J. D. (1997). Food intake and diet selection in sheep: the effect of manipulating the rates of digestion of carbohydrates and protein of the foods offered as a choice. British Journal of Nutrition 77, $243-254$.

Kyriazakis, I., Oldham, J. D., Coop, R. L. \& Jackson, F. (1994). The effect of subclinical intestinal nematode infection on the diet selection of growing sheep. British Journal of Nutrition 72, 665-677.

Langvatn, R. \& Hanley, T. A. (1993). Feeding-patch choice by red deer in relation to foraging efficiency-an experiment. Oecologia 95, 164-170.

Launchbaugh, K. L. \& Provenza, F. D. (1993). Can plants practice mimicry to avoid grazing by mammalian herbivores? Oikos 66, 501-504.

Launchbaugh, K. L., Provenza, F. D. \& Burritt, E. A. (1993). How herbivores track variable environments: Response to variability of phytotoxins. Journal of Chemical Ecology 19, 1047-1056.

Launchbaugh, K. L., Provenza, F. D. \& Werkmeister, M. J. (1997). Overcoming food neophobia in domestic ruminants through addition of a familiar flavor and repeated exposure to novel foods. Applied Animal Behaviour Science 54, 327-334.

Lawler, I. R., Stapley, J., Foley, W. J. \& Eschler, B. M. (1998). An ecological example of conditioned flavor aversion in plant-herbivore interactions: the effect of terpenes of Eucalyptus leaves on feeding by common ringtail and brushtail possums. Joumal of Chemical Ecology in press.

Leek, B. F. (1977). Abdominal and pelvic visceral receptors. British Medical Bulletin 33, 163-168. 
McArthur, C., Hagerman, A. E. \& Robbins, C. T. (1991). Physiological strategies of mammalian herbivores against plant defenses. In Plant Defenses Against Mammalian Herbivory, pp. 103-114 [R.T. Palo and C.T. Robins, editors]. Boca Raton, FL: CRC Press.

Mach, E. (1960). The Science of Mechanics: a critical and historical account of its development. (Original English translation published 1893). LaSalle: Open Court Publishing.

Maçean, N. (1976). A River Runs through It, and other stories. Chicago, IL: University of Chicago Press.

McNulty, S. A., Porter, W. F., Mathews, N. E. \& Hill, J. A. (1997). Localized management for reducing white-tailed deer populations. Wildlife Society Bulletin 25, 265-271.

Maturana, H. R. \& Varela, F. J. (1980). Autopoiesis and Cognition: the realization of the living. Dordrecht: Reidel.

May, R. M. (1986). When two and two do not make four: nonlinear phenomena in ecology. Proceedings of the Royal Society of London B 228, 241-266.

Mehansho, H., Hagerman, A., Clements, S., Butler, L., Rogler, J. \& Carlson, D. M. (1983). Modulation of proline-rich protein biosynthesis in rat parotid glands by sorghums with high tannin levels. Proceedings of the National Academy of Sciences of the USA 80, 3948-3952.

Mei, N. (1985). Intestinal chemosensitivity. Physiological Reviews 65, 211-237.

Millonas, M. M. (1992). A connectionist type model of self-organized foraging and emergent behaviour in ant swarms. Journal of Theoretical Biology 159, 529-552.

Mirza, S. N. \& Provenza, F. D. (1990). Preference of the mother affects selection and avoidance of foods by lambs differing in age. Applied Animal Behaviour Science 28, 255-263.

Mirza, S. N. \& Provenza, F. D. (1992). Effects of age and conditions of exposure on maternally mediated food selection by lambs. Applied Animal Behaviour Science 33, 35-42.

Mortis, R. (1993). Cosmic Questions. New York: Wiley.

Naim, M., Brand, J. G. \& Kare, M. R. (1986). Role of variety of food flavor in fat deposition produced by 'cafeteria' feeding of nutritionally controlled diets. In Interaction of the Chemical Senses with Nutrition, pp. 269-292 [M.R. Kare and J.G. Brand, editors]. New York: Academic Press.

Nolte, D. L. \& Provenza, F. D. (1991). Food preferences in lambs after exposure to flavours in milk. Applied Animal Behaviour Science 32, 381-389.

Nolte, D. L., Provenza, F. D., Callan R. \& Panter, K. E. (1992). Garlic in the ovine fetal environment. Physiology \& Behavior 52, 1091-1093.

O'Reagain, P. J., Goetsch, B. C. \& Owen-Smith, R. N. (1996). Effect of species composition and sward structure on the ingestive behaviour of cattle and sheep grazing South African sourveld. Jourmal of Agricultural Science 127 , 271-280.

Ortega-Reyes L. \& Provenza, F. D. (1993). Amount of experience and age affect the development of foraging skills of goats browsing blackbrush (Coleogyne ramosissima). Applied Animal Behaviour Science 36, 169-183.

Ortega-Reyes, L., Provenza, F. D., Parker, C. F. \& Hatfield, P. G. (1992). Drylot performance and ruminal papillae development of lambs exposed to a high concentrate diet while nursing. Small Ruminant Research 7, $101-112$.

Owen-Smith, R. N. (1993). Evaluating optimal diet models for an African browsing ruminant, the kudu: how constraining are the assumed constraints? Evolutionary Ecology 7, 499-524.

Perez, C., Ackroff, K. \& Sclafani, A. (1996). Carbohydrate- and protein-conditioned flavor preferences: effects of nutrient preloads. Physiology and Behavior 59; 467-474.

Pfister, J. A., Provenza, F. D., Manners, G. D., Gardner D. R. \& Ralphs, M. H. (1997). Tall larkspur ingestion: Can cattle regulate intake below toxic levels? Journal of Chemical Ecology 23, 759-777.

Phillips, R. J. \& Powley, T. L. (1996). Gastric volume rather than nutrient content inhibits food intake. American Journal of Physiology 271, R766-R779.

Piersma, T. \& Lindstrom, A. (1997). Rapid reversible changes in organ size as a component of adaptive behaviour. TREE 12, $134-138$.

Prigogine, I. (1980). From Being to Becoming: time and complexity in the physical sciences. San Francisco, CA: Freeman.

Prigogine, I. \& Stengers, I. (1984). Order Out of Chaos: man's new dialogue with nature. New York: Bantam Books.

Provenza, F. D. (1977). Biological Manipulation of Blackbrush (Coleogyne ramosissima Torr.) by Browsing with Goats. MS thesis, Utah State University.

Provenza, F. D. (1995). Postingestive feedback as an elementary determinant of food preference and intake in numinants. Journal of Range Management 48, 2-17.

Provenza, F. D. (1996). Acquired aversions as the basis for varied diets of ruminants foraging on rangelands. Joumal of Animal Science 74, $2010-2020$.

Provenza, F. D. (1997). Feeding behavior of animals in response to plant toxicants. In CRC Handbook of Plant and Fungal Toxicants, pp. 231-242 [J.P.F. D'Mello, editor]. Boca Raton, FL: CRC Press Inc.

Provenza, F. D. \& Balph, D. F. (1988). Development of dietary choice in livestock on rangelands and its implications for management. Journal of Animal Science 66, 2356-2368.

Provenza, F. D. \& Balph, D. F. (1990). Applicability of five diet-selection models to various foraging challenges ruminants encounter. In Behavioural Mechanisms of Food Selection (NATO ASI Series G: Ecological Sciences, vol. 20) pp. 423-459 [R.N. Hughes, editor]. Heidelberg: Springer-Verlag.

Provenza, F. D. \& Burritt, E. A. (1991). Socially-induced diet preference ameliorates conditioned food aversion in lambs. Applied Animal Behaviour Science 31, 229-236. 
Provenza, F. D., Burritt, E. A., Clausen, T. P., Bryant, J. P., Reichardt P. B. \& Distel R. A. (1990). Conditioned flavor aversion: a mechanism for goats to avoid condensed tannins in blackbrush. American Naturalist 136, 810-828.

Provenza, F. D. \& Cincotta, R. P. (1993). Foraging as a self-organizational learning process: accepting adaptability at the expense of predictability. In Diet Selection: an interdisciplinary approach to foraging behaviour, pp. 78-101 [R.N. Hughes, editor]. London: Blackwell Scientific Publications.

Provenza, F. D., Lynch, J. J., Burritt, E. A. \& Scott, C. B. (1994a). How goats learn to distinguish between novel foods that differ in postingestive consequences. Journal of Chemical Ecology 20, 609-624.

Provenza, F. D., Lynch, J. J. \& Cheney, C. D. (1995). Effects of a flavor and food restriction on the response to novel foods by sheep. Applied Animal Behaviour Science 43, 83-93.

Provenza, F. D., Lynch, J. J. \& Nolan, J. V. (1993a). The relative importance of mother and toxicosis in the selection of foods by lambs. Joumal Chemical Ecology 19, 313-323.

Provenza, F. D., Lynch, J. J, \& Nolan, J. V. (1994b). Food aversion conditioned in anesthetized sheep. Physiology \& Behavior 55, 429-432.

Provenza, F. D., Nolan, J. V \& Lynch, J. J. (1993b). Temporal contiguity between food ingestion and toxicosis affects the acquisition of food aversions in sheep. Applied Animal Behaviour Science 38, 269-281.

Provenza, F. D., Pfister, J. A. \& Cheney, C. D. (1992). Mechanisms of learning in diet selection with reference to phytotoxicosis in herbivores. Journal of Range Management 45, 36-45.

Provenza, F. D., Scott, C. B., Phy, T. S. \& Lynch, J. J. (1996). Preference of sheep for foods varying in flavors and nutrients. Journal of Animal Science 74, 2355-2361.

Provenza, F. D., Villalba, J. J. \& Augner, M. (1998). The physics of foraging. Proceedings, International Grassland Congress XVIII, in press.

Ralphs, M. R. (1997). Persistence of aversions to larkspur in naive and native cattle. Journal of Range Management 50 , 367-370.

Ramirez, I. (1997). Intragastric carbohydrate exerts both intake-stimulating and intake-suppressing effects. Behavioral Neuroscience 111, 612-622.

Revusky, S. H. \& Bedarf, E. W. (1967). Association of illness and prior ingestion of novel foods. Science 155, $219-220$.

Ricardo, J. A. \& Koh, E. T. (1978). Anatomical evidence of direct projections from the nucleus of the solitary tract to the hypothalamus, amygdala, and other forebrain structures in the rat. Brain Research 153, 1-26.

Rolls, B. J. (1986a). Sensory-specific satiety. Nutrition Reviews 44, 93-101.

Rolls, B. J., Van Duijvenvoorde, P. M. \& Rolls, E. T. (1984). Pleasantness changes and food intake in a varied fourcourse meal. Appetite 5, 337-348.

Rolls, E. T. (1986b). Neuronal activity related to the control of feeding. In Feeding Behavior, Neural and Humoral Controls, pp. 163-190 [R. C. Ritter, S. Ritter and C. D. Barnes, editors]. New York: Academic Press.

Ryle, G. (1949). The Concept of Mind. Chicago, IL: University of Chicago Press.

Sclafani, A. (1996). How food preferences are learned: laboratory animal models. Proceedings of the Nutrition Society 54, 419-427.

Scott, C. B., Banner, R. E. \& Provenza, F. D. (1996). Observations of sheep foraging in familiar and unfamiliar environments: familiarity with the environment influences diet selection. Applied Animal Behaviour Science 49. 165-171.

Scott, C. B., Provenza, F. D. \& Banner, R. E. (1995). Dietary habits and social interactions affect choice of feeding location by sheep. Applied Animal Behaviour Science 45, 225-237.

Scott, L. L. \& Provenza, F. D. (1998), Variation among sheep in food selection: effects of basal ration and foods offered in a meal. Journal of Animal Science in press.

Scott, T. R. (1990). Gustatory control of food selection. In Handbook of Behavioral Neurobiology, vol. 10, pp. 243-263 [E.M. Stricker, editor]. New York: Plenum Press.

Seynaeve, C., De Mulder, P. H. M. \& Verweij, J. (1991). Pathophysiology of cytotoxic drug-induced emesis: far from crystal-clear. Pharmaceutisch Weekblad, Scientific Edition 13, 1-6.

Shatz, C. J. (1992). The developing brain. Scientific American 267 (3), 61-67.

Simpson, S. J. \& Raubenheimer, D. (1993). A multi-level analysis of feeding behaviour: the geometry of nutritional decisions. Philosophical Transactions of the Royal Society of London B Biological Sciences 342, 381-402.

Skinner, B. F. (1938). The Behavior of Organisms: an experimental analysis. New York: Appleton-Century-Crofts.

Skinner, B. F. (1981). Selection by consequences. Science 213, 501-504.

Skinner, B. F. (1984). The evolution of behavior. Joumal of the Experimental Analysis of Behavior 41, $217-221$.

Solé, R.V., Miramontes, O. \& Goodwin, B. C. (1993). Oscillations and chaos in ant societies. Joumal of Theoretical Biology 161, 343-357.

Squibb, R. C., Provenza, F. D. \& Balph, D. F. (1990). Effect of age of exposure on consumption of a shrub by sheep. Journal of Animal Science 68, 987-997.

Stebbins, G. L. (1981). Coevolution of grasses and herbivores. Annals of the Missouri Botanical Garden 68, $75-86$.

Stickland, T. R., Britton, N. F. \& Franks, N. R. (1995). Complex trails and simple algorithms in ant foraging. Proceedings of the Royal Society of London $B$ 260, 53-58.

Sutcliffe, A. J. (1977). Further notes on bones and antlers chewed by deer and other ungulates. Jourmal of the British Deer Society 4, 73-82.

Swithers, S. E. \& Hall, W. G. (1994). Does oral experience terminate ingestion? Appetite 23, 113-138. 
Swithers-Mulvey, S. E., Miller, G. L. \& Hall, W. G. (1991). Habituation of oromotor responding to oral infusions in rat pups. Appetite 17, 55-67.

Tausch, R. J., Wigand, P. E. \& Burkhardt, J. W. (1993). Viewpoint. Plant community thresholds, multiple steady states, and multiple successional pathways: legacy of the Quatemary? Journal of Range Management 46, 439-447.

Thorhallsdottir, A. G., Provenza, F. D. \& Balph, D. F. (1990). Social influences on conditioned food aversions in sheep. Applied Animal Behaviour Science 25, 45-50.

Tien, D. V., Lynch, J. J., Hinch, G. N. \& Nolan, J. V. (1998). Grass odor and flavour overcome feed neophobia in sheep. Small Ruminant Research in press.

Toates, F. M. (1997). Has pure ethology the right foundations for applied ethology? Applied Animal Behaviour Science 53, $1-13$.

Van Soest, P. J. (1994). Nutritional Ecology of the Ruminant, 2nd edn. Ithaca, NY: Cornell University Press.

van Wieren, S.E. (1996). Do large herbivores select a diet that maximizes short-term energy intake? Forest Ecology and Management 88, 149-156.

Villalba, J. J. \& Provenza, F. D. (1996). Preference for flavored wheat straw by lambs conditioned with intraruminal administrations of sodium propionate. Journal of Animal Science 74. 2362-2368.

Villalba, J. J. \& Provenza, F. D. (1997a). Preference for wheat straw by lambs conditioned with intranuminal infusions of starch. British Journal of Nutrition 77, 287-297.

Villalba, J. J. \& Provenza, F. D. (1997b). Preference for flavoured foods by lambs conditioned with intranuminal administration of nitrogen. British Joumal of Nutrition 78, 545-561.

Villalba, J. J. \& Provenza, F. D. (1997c). Preference for flavoured wheat straw by lambs conditioned with intranuminal infusions of acetate and propionate. Journal of Animal Science 75, 2905-2914.

Villalba, J. J. \& Provenza, F. D. (1998a). Nutrient-specific preferences by lambs conditioned with intraruminal infusions of starch, casein, and water. Journal of Animal Science in press.

Villalba, J. J. \& Provenza, F. D. (1998b). Discriminating among foods: effects of energy provision on preferences of lambs for poor-quality foods. Applied Animal Behaviour Science in press.

Villalba, J. J. \& Provenza, F. D. (1998c). Effects of food structure and nutritional quality and animal nutritional state on intake behaviour and food preferences of sheep. Applied Animal Behaviour Science in press.

Wallis de Vries, M. F. (1994). Foraging in a Landscape Mosaic: Diet Selection and Performance of Free-Ranging Carlle in Heathland and Riverine Grassland. PhD thesis, Wageningen.

Wang, J. \& Provenza, F. D. (1996a). Food preference and acceptance of novel foods by lambs depend on the composition of the basal diet. Journal of Animal Science 74, 2349-2354.

Wang, J. \& Provenza, F. D. (1996b). Food deprivation affects preference of sheep for foods varying in nutrients and a toxin. Journal of Chemical Ecology 22, 2011-2021.

Wang, J. \& Provenza, F. D. (1997). Dynamics of preference by sheep offered foods varying in flavors, nutrients, and a toxin. Journal of Chemical Ecology 23, 275-288.

Warren, J. T. \& Mysterud, I. (1993). Extensive ranging by sheep released onto an unfamiliar range. Applied Animal Behaviour Science 38, 67-73.

Westoby, M. (1978). What are the biological bases of varied diets? American Naturalist 112, 627-631.

Wilmshurst, J. F., Fryxell, J. M. \& Hudson, R. J. (1995). Forage quality and patch choice by wapiti (Cervus elaphus). Behavioral Ecology 6, 209-217.

Wilson, E. O. (1998). Consilience: the unity of knowledge. New York: Alfred A. Knopf Inc.

Wooley, O. W., Wooley, S. C. \& Dunham, R. B. (1972). Calories and sweet taste: effects on sucrose preference in the obese and nonobese. Physiology and Behavior 9, 765-768.

Wu, J. \& Loucks, O. L. (1995). From balance of nature to hierarchical patch dynamics: a paradigm shift in ecology. Quarterly Review of Biology 70, 439-466.

Yuan, C.-S. \& Barber, W. D. (1992). Hypothalamic unitary responses to gastric vagal input from the proximal stomach. American Journal of Physiology 262, G74-G80. 